\title{
INITIATIVES TO REVISE THE ROMANIAN CONSTITUTION OF 2019. BRIEF PRESENTATION OF THE DECISIONS OF THE CONSTITUTIONAL COURT
}

DOI:10.47743/rdc-2020-1-0005

\author{
Iulia-Elena NISTOR \\ PhD Assistant professor, \\ Faculty of Law, \\ "Titu Maiorescu" University of Bucharest
}

\section{Abstract}

The study presents the case law of the Constitutional Court in the matter of Romanian Constitutional revision with reference to the legislative proposals examined by the court of constitutional jurisdiction during 2019. We notice a preoccupation of the title holders of the right of legislative initiative in the field of combating corruption through various means. Thus, the authors of the legislative proposals wanted to regulate, at constitutional level, integrity conditions that would apply: to the candidates to be elected in the local public administration bodies, in the Chamber of Deputies, in the Senate and in the position of President of Romania and limit the possibility of regulating/granting collective amnesty and pardon and individual pardon for acts of corruption. At the same time, the purpose of initiating these legislative proposals concerns imposing a limit to regulations by means of emergency ordinances in the field of crimes, punishments and the regime of their enforcement.

Keywords: Constitutional revision; equality of rights; the right to be elected; amnesty; pardon; human dignity; Government emergency ordinances; constitutional review; the role of the Ombudsman

In 2019, the Constitutional Court ruled on three proposals to revise the Constitution, initiated by citizens and, respectively, by deputies and senators. We will further present the subject of the Constitutional revision proposals and the rulings of the Constitutional Court.

- The first of these, in chronological order (No. 237 of May 7, 2019), was initiated by the citizens of the counties: Alba, Arad, Argeş, Bacău, Bihor, Bistriţa-Năsăud, Botoşani, Braşov, Brăila, Bucharest, Buzău, Caraş-Severin, Călăraşi, Cluj, Constanţa, Covasna, Dâmboviţa, Dolj, Galaţi, Giurgiu, Gorj, Harghita, Hunedoara, lalomiţa, Iaşi, Ilfov, 
Maramureş, Mehedinţi, Mureş, Neamţ, Olt, Prahova, Satu Mare, Sălaj, Sibiu, Suceava, Teleorman, Timiş, Tulcea, Vaslui, Vâlcea, Vrancea and it aims to complete Article 37 the Right to be elected, from Title II of the Constitution - Fundamental rights, freedoms and duties, with a new paragraph, în the present case with a condition concerning the exercise of the right to be elected.

The proposal to revise the Constitution is worded as follows:

"Article I - After paragraph 2 of Article 37 of The Constitution of Romania, revised by Law No. 429/2003, approved by the national referendum held on 18-19 October 2003, and republished in the Official Gazette of Romania, Part I, No. 767 of 31 October2003, a new paragraph 3 shall be inserted, with the following wording:

"(3) Persons who have been definitively sentenced to custodial sentences for intentional offences cannot be elected as members of local public administration bodies, the Chamber of Deputies, the Senate, or to the office of President of Romania, until a situation which removes the consequences of the conviction has occurred " ".

Examining the proposed text, the Court held that it did not question the national, independent, unitary and indivisible character of the Romanian state, the republican form of government, the integrity of the territory, the independence of the judiciary, political pluralism and the official language, listed in Article 152 (1) of the Constitution. Therefore, the analysis referred only to the provisions of Article 152 (2), regarding the suppression of the fundamental rights and freedoms of the citizens or of their guarantees. Constitutional provisions being applicable, which regulate fundamental rights, the Court noted, in carrying out this analysis, the incidence of the provisions of Article 20 of the Constitution, in the sense of interpreting the constitutional provisions in accordance with the human rights treaties to which Romania is party, and the priority of the latter when they contain more favorable provisions, as well as with the principles applicable to the fundamental rights and freedoms enshrined in the Constitution.

The Court found that the proposed revision was not intended to abolish the right to be elected or a guarantee thereof within the meaning of Article 152 (2) of the Constitution, but to restrict that right. Analyzing the relevant constitutional principles, the Court noted that the guarantee of exclusively political rights, of which the right to be elected is a part, constitutes the basis of the democratic state, within the meaning of Article 1 (3) of the Constitution, and the aim pursued by the initiators is to establish clear and objective criteria of integrity regarding the elected representatives of the people, criteria subsumed to this desideratum. With regard to establishing the legitimacy and assessing the proportionality of the restriction of the fundamental right to be elected, in relation to the purpose pursued by the initiators, the Court referred to Decision No. 304 of May 4, 2017, by which it ruled on the exception of unconstitutionality of the provisions of Article 2 with reference to the phrase "did not suffer criminal convictions" from Law No. 90/2001 on the organization and functioning of the Romanian Government and ministries, an exception raised directly by the 
Ombudsman. On that occasion, the Court held that the measure criticized in that case has a legitimate purpose, namely the requirement of morality, integrity, probity and honesty which must be demonstrated by any person aspiring to access to public office or dignity. It is also appropriate in the sense that the aforementioned legitimate aim can be achieved in the abstract by the condition imposed by the legislator, necessary in a democratic society in the sense that the social acceptance of the person wishing to accede to the position of member of the Government is all the greater as it has provided evidence of correction in an extended time interval deemed sufficient by the legislator, and by applying the criminal norms of substantial law regarding the nonpenal consequences of the conviction, such a condition is proportional to the legitimate aim pursued, being a guarantee, on the one hand, of the person's correction and, on the other hand, of his social reintegration" (paragraph 38). Rejecting the exception raised as inadmissible, however, the Court held that it was in the duty of "of Parliament to achieve a necessary correlation between the conditions of access to the position of member of the Government and that of member of Parliament, having regard, on the one hand, to the compatibility between the two public offices and, on the other hand, to the requirement that representatives of the two powers of the State enjoy similar conditions of access to office, avoiding the situation that, although compatible at constitutional level, the two functions should become incompatible by the effect of an infra-constitutional legislation, in the sense that the law imposes additional conditions that make them de iure incompatible to be exercised simultaneously" (paragraph 28). The statutes of the Constitutional Court cited above do not exclude the possibility of a correlation in the sense of raising the integrity criteria regulated by the legislator for ministers to the rank of constitutional eligibility criteria for elected representatives of the people, provided that the conditions of proportionality developed by the same decision are observed. Therefore, such a measure appears to be an opportunity, in the discretion of the constituent legislator.

With regard to the proportionality and reasonableness of such a measure, the Court held that "is the exclusive right of the legislator to intervene and to circumstance the scope of incidence of limitations, prohibitions, as well as incapacities resulting from the conviction. (...) The legislator is free to choose between the imposition of a general ban; - the absence of any criminal conviction, as currently regulated, and the imposition of a special interdiction, circumscribed to a limited scope of criminal convictions, based on criteria such as the nature of the offenses committed, the subjective side, the enforced sentence. (...) The freedom of the legislator to regulate this field must respect the purpose of the legislation, that of ensuring the integrity of the mandate of the ministers, as well as the legislative framework in this matter. Consequently, the legislator must also take into account the fact that the prohibitions must be regulated in 
a reasonable and proportionate way in relation to the situation that determined them, avoiding the establishment in the positive law of absolute and perpetual prohibitions" (paragraph 42).

The Court found that the initiators circumscribed the proposed condition, in accordance with the considerations of the Constitutional Court in the aforementioned decision, in the sense that the special interdiction is within the discretion of the legislator and is limited to a limited sphere of criminal convictions, which is based on the criterion of the subjective side and the enforced sentence. Furthermore, the prohibition is not perpetual, but subsists until the occurrence of a situation which removes the consequences of conviction. Consequently, within the meaning of the Court's decision, "persons who fall under/are beneficiaries of a decriminalization or amnesty or (...) rehabilitation law (...), persons in respect of whom the criminal conviction ceases to produce the non-penal effects provided by law" may be elected under the conditions of Article 37 of the Constitution as amended by the proposal made. Therefore, a restriction of the right to be elected which is likely to affect its substance; and no lack of proportionality of the proposed measure, likely to be assimilated to a suppression of the right to be elected or a guarantee thereof, prohibited by Article 152 (2) of the Constitution cannot be retained.

With reference to the relevant case law of the ECHR, the court held, in essence, that "the rights guaranteed under Article 3 of Protocol No. 1 of the European Convention on Human Rights are essential for establishing and maintaining the foundations of an effective and genuine rule of law (...). However, the rights enshrined in Article 3 of Protocol No. 1 are not absolute, there is room for implicit limitations, so that states can benefit from a margin of appreciation in this area. Thus, the conditions imposed must not impede the free expression of the people in the choice of the legislature, but also prevent a democratic society from taking measures to protect itself against activities intended to destroy the rights or freedoms set out in the Convention. Article 3 of Protocol No. 1, which enshrines the person's ability to influence the composition of the legislature, therefore does not exclude the imposition of restrictions on the electoral rights of a person who, for example, has committed serious abuses in a public position or whose behavior risks undermining the rule of law or the democratic foundations (...) However, the severe measure of deprivation of the right to vote should not be easily resorted to, as the principle of proportionality imposes an obvious and sufficient link between the sanction and the circumstances and behavior of the individual to whom it relates. (...) As in other contexts, an independent court, which applies an adversarial procedure, provides strong protection against arbitrariness" (paragraphs 58-62 and 71).

With regard to the relevant benchmark system at Council of Europe level, the Constitutional Court also invoked the recommendations of the Venice Commission which, at its Plenary Session on 23-24 October 2015, reviewed international standards 
on the right to vote and restrictions, including with reference to the distinction which the ECHR makes between the (active) right to vote and the (passive) right to be elected. Explaining the Code of Good Practice in Electoral Matters in the light of ECHR case law, the Commission noted that "having regard to the recent case law of the European Court of Human Rights, paragraph I.1.1.d.v, of the code of good practices mentioned in electoral matters should not be taken literally, as imposing a specific decision in each case" (paragraph 24). On the basis of the applicable European standards and information on the legal situation in the states whose legislation has been examined, the Venice Commission has set out a number of conclusions in that report and considers it appropriate that the Constitution should regulate "at least the most important aspects of the restrictions on the right to be elected and the loss of the parliamentary mandate" (paragraph 179). It might be appropriate that "the legislation should provide for restrictions to work automatically for the most serious offenses or sentences - as is the case in most states concerned -, and the assessment of judges in making such decisions in specific cases may be appropriate in less serious cases and, in general, if the conviction relates to Members of Parliament in office" (paragraph 180).

In conclusion, the Court found that the proposal to revise the Constitution in order to introduce the condition as circumscribed by the initiators is in line with the constitutional requirement, not being likely to lead to the suppression or restriction of the right to be elected which would be prejudicial to its substance. Thus, the legislative proposal for the revision of the Romanian Constitution (PI-x 237/07.05.2019) was initiated in compliance with the constitutional provisions establishing the procedure and limits of the revision ${ }^{1}$.

- The next two revision initiatives, by Deputies and Senators, have a similar purpose.

Thus, legislative proposal No. 331/03.07.2019 was initiated by a number of 115 deputies and has the following wording:

"Article I - The Constitution of Romania, revised by Law No. 429/2003, approved by the national referendum held on 18-19 October 2003, and republished in the Official Gazette of Romania, Part I, No. 767 of 31 October 2003, shall be amended and completed as follows:

1. After paragraph 2 of Article 37, a new paragraph 3 shall be inserted, with the following wording:

Article 37 - The Right to be Elected

"(3) Persons who have been definitively sentenced to custodial sentences for intentional offences cannot be elected as members of local public administration bodies,

${ }^{1}$ Decision No. 222 of April 9, 2019 on the legislative proposal to revise the Romanian Constitution [Pl-x 237/07.05.2019], published in the Official Gazette of Romania, Part I, No. 425 of May 30, 2019.

CONSTITUTIONAL NEWS 
the Chamber of Deputies, the Senate, or to the office of President of Romania, until a situation which removes the consequences of the conviction has occurred".

Article 38 shall be amended and supplemented as follows:

Article 38 - Right to be elected to the European Parliament

"Given Romania's accession to the European Union, Romanian citizens shall have the right to elect and be elected to the European Parliament. Citizens who have been definitively sentenced to custodial sentences for intentional offences cannot be elected to the European Parliament, until a situation that removes the consequences of the conviction has occurred.

3. In paragraph 3 of Article 73, subparagraph (i) shall be amended and shall read as follows:

Article 73 - Categories of laws

“(3) Organic laws shall regulate:

[...]

i) the granting of amnesty or collective pardon. The granting of amnesty and collective pardon for corruption offences shall be prohibited".

4. Paragraph 2 and paragraph 3 of Article 74 shall be amended and shall read as follows:

Article 74 - Legislative initiative

"(2) Tax issues, international issues, amnesty and pardon cannot be the subject of citizens' legislative initiatives. Amnesty and collective pardon in respect of corruption offences cannot be the subject of Deputies or Senators' legislative initiatives.

(3) The Government shall exercise its legislative initiative by sending the draft law to the Chamber responsible for adopting it, as the first notified Chamber. Amnesty and collective pardon in respect of corruption offences cannot be the subject of the Government's legislative initiatives."

5. Subparagraph (d) of Article 94 shall be supplemented and shall read as follows:

Article 94 -Other powers

"The President of Romania shall also have the following powers:

[...]

d) to grant individual pardon. The granting of individual pardons for corruption offences shall be prohibited".

6. Paragraph 6 of Article 115 shall be amended and supplemented and shall read as follows:

Article 115 - Legislative delegation

[...]

"(6) Emergency ordinances cannot be adopted in the field of constitutional laws, in the field of organic laws having the subject of regulation provided for in Article 73 (3) (h), (i) and (I), or affect the status of fundamental institutions of the State, the rights, freedoms and duties stipulated in the Constitution, the electoral rights, and cannot establish steps for transferring assets to public property forcibly." 
7. In Article 146, after subparagraph (a), a new subparagraph ( $\left.a^{1}\right)$ shall be inserted, with the following wording, and the subparagraph (d) of Article 146 shall be amended as follows:

Article 146 - Powers

"The Constitutional Court shall have the following powers:

[...]

$\left.a^{1}\right)$ to adjudicate on the constitutionality of ordinances, upon notification by the President of Romania, a number of at least 50 Deputies or at least 25 Senators, the High Court of Cassation and Justice or the Advocate of the People;

[...]

d) to decide on exceptions as to the unconstitutionality of laws and ordinances, brought up before courts of law or commercial arbitration;".

Examining the legislative proposal to revise the Constitution, the Court held that by the sole article pt. 1 [with reference to Article 37 (3)] from the legislative proposal, a new prohibition is established for citizens with definitive custodial sentences for crimes committed with intent regarding their election in the local public administration bodies, in the Chamber of Deputies, in the Senate and in the position of President of Romania. Similar to the previous revision proposal, the considerations for which the Court found that this proposal was unconstitutional were also taken into account here, mutatis mutandis.

However, the Court noted that the analyzed text is not correlated with Article 16 (4) of the Constitution, as it only refers to Romanian citizens. Therefore, the citizen of the European Union, who does not hold Romanian citizenship, would be allowed to be elected in the local public administration authorities, even if they have been definitely to a definite custodial sentence for intentional offences. The Court also noted that the proposed text was too detailed for constitutional regulation. These regulations must be as general as possible, the task of detailing them falling to the lower normative acts. The more detailed the constitutional text, the more exposed it is to relatively frequent changes.

With regard to Article I point 2 [by reference to Article 38] of the legislative proposal, the Court noted that it introduces a legislative solution similar to that provided for in Article I point 1 regarding the right to be elected to the European Parliament. Consequently, the above arguments apply to this point as well.

With regard to Article I point 3 [by reference to Article 73 (3) (i)], point 4 [by reference to Article 74 (2) and (3)] and point 5 [by reference to Article 94 (d)] of the legislative proposal, The Court found that they limit public power by removing the state's power to grant amnesty or pardon (collective or individual) for "acts of corruption". The Constitution may provide for the limitation of public power, for the benefit of the citizen or of values of general interest, in order to avoid the abuse of 
power. According to Article 152 (2) of the Constitution, constitutional revisions must give increasing protection to fundamental rights and freedoms.

Although the general prohibition on granting amnesty or pardon in respect of "acts of corruption" concerns one side of public power, the Court has ruled that this prohibition affects the principle of equality and human dignity as well as the guarantees associated with it. As a result of the aforementioned prohibition, it is clear that two categories of citizens are treated differently. The first category, which includes persons convicted of corruption offenses, cannot benefit from amnesty or pardon, while the second category, which includes persons convicted of any offenses other than corruption, can benefit from them. Such a difference in treatment has no objective and reasonable justification, as the reason for amnesty and pardon does not consider the crime committed, but non-penal, even non-legal, aspects of humanity, opportunity, public perception or other circumstances that justify the exercise of this prerogative of the state. Thus, even the reason of the two criminal law institutions is annihilated. It reaches the ostracization of a category of citizens, by denying the prerogative of the state to forget or forgive the deed committed. These citizens would become discriminated even by the express declaration of the fundamental law, an aspect that is unacceptable in the light of the principle of equality. The Court thus found a breach of the principle of equality, in its non-discrimination component. In connection to Article 152 (2) of the Constitution, this violation is a suppression of a constitutional guarantee associated with fundamental rights and freedoms.

Also, the proposed revision places people who have committed acts of corruption in a situation of inferiority, which is a violation of their human dignity. Title II of the Constitution does not include human dignity in fundamental rights and freedoms, but in supreme values, but the fundamental rights and freedoms of citizens and their guarantees cannot be considered a diffuse set of elements lacking any connection between them, but they form a coherent and unitary system of values, based on human dignity. It follows that any violation of the aforementioned fundamental rights and freedoms is a violation of human dignity.

The Court also noted that such a constitutional revision conflicts with the overall view of the original constituent legislature on how to grant amnesty and pardon. Thus, it excluded the citizens' legislative initiative on amnesty and pardons, leaving only the possibility for parliamentarians and the Government to initiate in this regard a legislative proposal or a draft law [Article 74 (2) of the Constitution)], in order to avoid an emotional and subjective appreciation from the citizens. From the perspective of public perception, the severity of the social danger of various categories of offenses is perceived differently over time. Due to these variations, the exclusion from the start, through the Constitution, of corruption offenses from the possibility of amnesty or pardon deprives the competent authorities of the possibility to assess their severity, 
danger and social impact on a case-by-case basis. Situations of obvious discrimination and weakening of the state authority can be created precisely in the exercise of certain public prerogatives in favor of the citizens.

Thus, the scope of amnesty and pardon cannot be limited by a general constitutional rule, as such a limitation is contrary to Article 152 (2) in conjunction with Article 16 of the Constitution. Also, no general rule of law could limit the scope of amnesty and pardon, as it would be contrary to Article 16 of the Constitution. The identified constitutional law issue does not concern the level of regulation, but the impossibility of regulating such normative solution, which distort the legal regime of amnesty and pardon and limit the discretionary power of the Romanian Parliament or of the President of Romania, as the case may be. Given the discretionary power it enjoys, the Parliament or the President of Romania may grant, by law or decree, amnesty or collective or individual pardon only for a certain amount of the penalty or for certain offenses, without raising the issue, in this case, of the violation of Article 16 of the Constitution. The establishment, on a case-by-case basis, of the amount of penalty and/or offenses for which amnesty or pardon is granted rests with the Parliament and the President of Romania, on the occasion of adopting the actual law granting amnesty or collective pardon or issuing the individual pardon decree.

In conclusion, the Court found that Article I (3) [by reference to Article 73 (3) (I)], point 4 [by reference to Article 74 (2) and (3)] and point 5 [by reference to Article $94 \mathrm{~d}$ )] of the legislative proposal infringes the limits of the revision provided for in Article 152 (2) of the Constitution, in conjunction with Article 1 (3) and Article 16 of the Constitution.

Article I (6) [by reference to Article 115 (6)] of the legislative revision proposal prohibits the adoption of emergency ordinances in the field of crimes, punishments and their execution, granting amnesty or collective pardon and the organization and functioning of Superior Council of Magistracy, of the courts, of the Public Ministry and of the Court of Accounts. The Court found that this provision does not infringe the limits of the revision, as the derived constituent legislature has the power to limit the scope of emergency ordinances.

Regarding Article I 7 [by reference to Article $146 \mathrm{a}^{1}$ )]; from the legislative revision proposal for the Constitution, the Court held that, in principle, the regulation of a constitutional revision exercised directly in relation to Government ordinances does not violate the limits of the revision provided for in Article 152 (2) of the Constitution.

However, the analyzed text is poorly written. Thus, it is not possible to determine whether a constitutional revision is regulated a priori or a posteriori. If it is considered that the analyzed text concerns an a priori constitutionality review, it is not correlated with Article 115 (1)-(3) and (5) on the Constitution. Regarding the emergency ordinances, considering the duration of the procedure before the Constitutional Court; if they were challenged through a priori constitutional review, they would have affected the legal regime of the emergency ordinance, as well as the Government's ability to respond effectively to an extraordinary situation. If, on the other hand, it is considered 
that the analyzed text concerns an a posteriori constitutionality review, it must be borne in mind that in legislative practice situations may arise in which the ordinance does not enter into force on the date of publication, but on another date provided for therein; in which case the Court would rule on a text which is not yet in force, which contradicts the notion of a posteriori review.

Article I 7 [by reference to Article $146 \mathrm{~d}$ )] from the legislative proposal proposes the elimination of the abstract $a$ posteriori constitutionality review exercised at the request of the Ombudsman. The Court has ruled that such a limitation of the scope of the Ombudsman affects their role in defending human rights against any violations, and therefore infringes the limits of the revision set out in Article 152 (2) of the Constitution.

In conclusion, the Court found that the legislative proposal to revise the Romanian Constitution (PI-x 331/3.07.2019) was initiated in compliance with the provisions of Article 150 (1) of the Constitution. It was also found that Article I 1 [by reference to Article 37 (3)], point 2 (by reference to Article 38), point 6 [with reference to Article 115 (6)] and point 7 [with reference to Article $\left.146 \mathrm{a}^{1}\right)$ ] of the legislative proposal to revise the Constitution does not violate the limits of the revision provided by Article 152 (2) of the Constitution. Whereas, Article I point 3 [by reference to Article 73 (3) i)], point 4 [by reference to Article 74 (2) and (3)], point 5 [by reference to Article $94 \mathrm{~d}$ )] and point 7 [by reference to Article $146 \mathrm{~d}$ )] of the legislative proposal for revision infringes the limits of the revision provided by Article 152 (2) of the Constitution. The Court has submitted to Parliament the observations on Article I point 1 [by reference to Article 37 (3)], point 2 [by reference to Article 38], point 6 [by reference to Article 115 (6)] and point 7 [by reference to Article $\left.146 \mathrm{a}^{1}\right)$ ] from the mentioned legislative proposal ${ }^{2}$.

Legislative proposal No. 332 of July 3, 2019 was initiated by a number of 131 Deputies and 9 Senators and has the following wording:

"Article I - The Constitution of Romania, revised by Law No. 429/2003, approved by the national referendum held on 18-19 October 2003, and republished in the Official Gazette of Romania, Part I, No. 767 of 31 October 2003, shall be amended and completed as follows:

1. After paragraph 2 of Article 37, a new paragraph $2^{1}$ shall be inserted, with the following wording:

" $\left.2^{1}\right)$ Persons who have been definitively sentenced to custodial sentences for intentional offences cannot be elected as members of local public administration bodies, the Chamber of Deputies, the Senate, or to the office of President of Romania, until a situation which removes the consequences of the conviction has occurred".

2. In Article 94, subparagraph (d) shall be amended and shall read as follows:

${ }^{2}$ Decision No. 464 of 18 July 2019 on the legislative proposal to revise the Constitution of Romania [Pl-x 331/3.07.2019], published in the Official Gazette of Romania, Part I, No. 646 of 5 August 2019.

\section{CONSTITUTIONAL LAW REVIEW}


Article 94 - Other powers

"The President of Romania shall also have the following powers:

[...]

d) to grant individual pardon; he cannot grant pardon for corruption offences".

3. In Article 115, paragraph 6 shall be amended and shall read as follows:

Article 115 - Legislative delegation

"Emergency ordinances cannot be adopted in the field of constitutional laws or affect the status of fundamental institutions of the State, the rights, freedoms and duties stipulated in the Constitution, the electoral rights, they cannot regulate in the field of offences, penalties or regime governing their execution, as well as of judicial organization, and cannot establish steps for transferring assets to public property forcibly."

4. In Article 146, a new subparagraph $\left(c^{1}\right)$ shall be inserted, with the following wording:

" $\mathrm{C}^{1}$ ) to adjudicate on the exceptions of unconstitutionality regarding ordinances, upon notification by the President of Romania, one of the presidents of the two Chambers, a number of at least 50 Deputies or at least 25 Senators; the exception may be submitted within 5 days of publication of the ordinance in the Official Gazette of Romania, Part l;".

Examining the legislative proposal to revise the Constitution, the Court noted that Article 37 (2) of the legislative proposal establishes a new prohibition on citizens definitively sentenced to custodial sentences for intentional offenses, regarding their election in the public administration bodies, in the Chamber of Deputies, in the Senate and in the position of President of Romania. It does not call into question the limits of the revision of the Constitution, for the same reasons shown with regard to the other two proposals with a similar content.

However, the Court found that the phrase "central and local public administration bodies" should be replaced by the phrase "local public administration bodies", as the occupation of public positions within the central public administration bodies is done by appointment, not by election. The Court also noted that the analyzed text is not correlated with Article 16 (4) of the Constitution, as it refers only to Romanian citizens. Therefore, the citizen of the European Union, who does not hold Romanian citizenship, would be allowed to be elected in the public administration authorities, even if he was definitively sentenced to a custodial sentence for intentional offenses. The Court also noted that the proposed text was too detailed for constitutional regulation. These regulations must be as general as possible, the task of detailing them falling to the lower normative acts. The more detailed the constitutional text, the more exposed it is to relatively frequent changes.

With regard to Article I point 2; [by reference to Article 94 (d)] of the legislative proposal, The Court found that it eliminates the attribution of the President of Romania 
of individual pardon for corruption offenses. The Constitution may provide for the limitation of public power, for the benefit of the citizen or of values of general interest, in order to avoid the abuse of power. According to Article 152 (2) of the Constitution, constitutional revisions must give increasing protection to fundamental rights and freedoms. Even if the general prohibition of individual pardons for corruption offenses concerns one side of public power, the Court has ruled that this prohibition affects the principle of equality and human dignity, as well as the guarantees associated with it. As a result of this prohibition, it is clear that two categories of citizens are treated differently. The first category, which includes persons convicted of corruption offenses, cannot benefit from individual pardon, while the second category, which includes persons convicted of any offenses other than corruption, can benefit from it. Such a difference in treatment does not have an objective and reasonable justification, as the reason for pardon does not take into account the offense committed, but non-penal, even non-legal, humanitarian, opportunity, public perception or other circumstances that justify the exercise of this state prerogative. Thus, even the reason for individual pardon is annihilated. It reaches the ostracization of a category of citizens, by denying the prerogative of the state to forgive the offense committed. These citizens would become discriminated even by the express declaration of the fundamental law, an aspect that is unacceptable in the light of the principle of equality. The Court thus found a breach of the principle of equality, in its non-discrimination component. Reported to Article 152 (2) of the Constitution, this violation is a suppression of a constitutional guarantee associated with fundamental rights and freedoms.

The proposed revision places people who have committed acts of corruption in a situation of inferiority, which is a violation of their human dignity, for which similar considerations are retained to those that concerned the previously reviewed revision proposal, with a similar content.

The Court also held, for reasons similar to those set out above, that such a constitutional revision conflicts with the overall view of the original constituent legislature as to how to grant pardon. Thus, it excluded the citizens' legislative initiative on pardons, leaving only the possibility for parliamentarians and the Government to initiate a legislative proposal or a draft law in this regard [Article 74 (2) of the Constitution], in order not to allow an emotional and subjective appreciation from the citizens. From the perspective of public perception, the severity of the social danger of various categories of offenses is perceived differently over time. Due to these variations, the exclusion from the start, through the Constitution, of corruption offenses from the possibility of individual pardon deprives the competent authorities of the possibility to assess their gravity, danger and social impact on a case-by-case basis. Situations of obvious discrimination and weakening of the state authority can be created precisely in the exercise of certain public prerogatives in favor of the citizens. Thus, the scope of individual pardon cannot be limited by a general constitutional rule, as such a limitation is contrary to Article 152 (2) in conjunction with Article 16 of the Constitution. Also, no 
general rule of law could limit the scope of individual pardon, because it would be contrary to Article 16 of the Constitution. The identified constitutional law issue does not concern the level of regulation, but the impossibility of regulating such a normative solution, which distorts the legal regime of individual pardon and limits the discretionary power of the President of Romania. Given the discretionary power they have, the President of Romania may grant, by decree, individual pardon only for a certain amount of punishment or for certain offenses, without raising the issue, in this case, of violating Article 16 of the Constitution. The establishment, from case to case, of the amount of the punishment and/or of the offenses for which the individual pardon is granted belongs to the President of Romania, on the occasion of issuing the decree of individual pardon.

Thus, Article I point 2 [by reference to Article 94 d)] of the legislative proposal infringes the limits of the revision provided by Article 152 (2) of the Constitution in conjunction with Article 1 (3) of the Constitution.

Regarding Article I point 3 [by reference to Article 115 (6)] from the legislative proposal for revision which prohibits the adoption of emergency ordinances in the field of crimes, punishments and the regime of their execution, as well as of the judicial organization, the Court held that it did not infringe the limits of the revision, as the derived constituent legislature has the power to limit the scope of the emergency order.

Regarding Article I point 4 [by reference to Article $146 c^{1}$ )] from the legislative proposal to revise the Constitution, the Court held that, in principle, the regulation of a constitutional review exercised directly in relation to Government ordinances does not violate the limits of the revision provided for in Article 152 (2) of the Constitution. However, the Court noted that the analyzed text was poorly worded. Thus, it is not possible to determine whether a constitutional review is a priori or a posteriori regulated. Considering that the final thesis of the text establishes that the notification is formulated within 5 days from the publication of the ordinance, it would result that it is a question of an a posteriori constitutionality review. In this case, it must be borne in mind that in legislative practice there may be situations in which the ordinance does not enter into force on the date of publication, but on another date provided for therein, in which case the Court would rule on a text which is not yet in force, which contradicts the notion of a posteriori review. The Court stressed that the constitutional court cannot substitute itself for the derived constituent legislator, interpreting the analyzed constitutional norm, in order to determine the legal regime of the regulated constitutionality review. Therefore, it is the responsibility of the derived constituent legislator to properly regulate the new normative solution. At the same time, the Court found that it is necessary to correlate the analyzed text with Article 147 (4) of the Constitution, in order to indicate the specific effects of the decisions of the Constitutional Court thus pronounced. 
In conclusion, the Court found that the legislative proposal to revise the Constitution of Romania (PI-x 332/3.07.2019) was initiated in compliance with the provisions of Article 150 (1) of the Constitution. It also found that Article I point 1 [by reference to Article $37\left(2^{1}\right)$ ], Article I point 3 [by reference to Article 115 (6)] and Article I point 4 [by reference to Article 146 point $\left(c^{1}\right)$ ] of the legislative proposal to revise the Constitution do not violate the limits of the revision provided for in Article 152 (2) of the Constitution. On the other hand, Article I point 2 [by reference to Article 94 (d)] of the legislative proposal for revision infringes the limits of the revision provided for in Article 152 (2) of the Constitution. The Court referred to the Parliament the observations on Article I point 1 [by reference to Article $37\left(2^{1}\right)$ ], Article I point 3 [by reference to Article $115(6)$ ] and Article I point 4 [by reference to Article 146 point $\left(c^{1}\right)$ ] of the aforementioned legislative proposal ${ }^{3}$.

The three legislative proposals analyzed followed the legislative procedure, and the case of the two proposals that had as initiators deputies and senators from the legislature 2016-2020 (PI-x No. 331/3.07.2019, PI-x No. 332/03.07.2019) the procedure ceased as a result of not complying with the provisions of Article 635 of the republished Romanian Constitution. The legislative proposal initiated by citizens (PI-x 237/07.05.2019) is undergoing the legislative procedure at the Romanian Senate.

${ }^{3}$ Decision No. 465 of 18 July 2019 on the legislative proposal to revise the Constitution of Romania [Pl-x 332/03.07.2019], published in the Official Gazette of Romania, Part I, No. 645 of 5 August 2019. 